\title{
UNDETECTABLE SERUM LEVELS OF ANTI-MÜLLERIAN HORMONE IN WOMEN WITH OVARIAN HYPERSTIMULATION SYNDROME DURING IN VITRO FERTILIZATION AND SUCCESSFUL PREGNANCY OUTCOME: CASE REPORT
}

\author{
Ivan Grbavac ${ }^{1}$, Ivana Zec ${ }^{2}$, Dejan Ljiljak ${ }^{1}$, Romina Rakoš Justament ${ }^{1}$, \\ Željka Bukovec Megla ${ }^{2}$ and Krunoslav Kuna ${ }^{1}$
}

\begin{abstract}
${ }^{1}$ Department of Gynecology and Obstetrics, Sestre milosrdnice University Hospital Centre, Zagreb, Croatia; ${ }^{2}$ Laboratory of Endocrinology, Oncology and Nuclear Medicine Departments, Sestre milosrdnice University Hospital Centre, Zagreb, Croatia
\end{abstract}

\begin{abstract}
SUMMARY - We report a unique case of undetectable serum levels of anti-müllerian hormone $(\mathrm{AMH})$ in women with polycystic ovary syndrome (PCOS) who developed ovarian hyperstimulation syndrome (OHSS) during in vitro fertilization (IVF). A case is described of a 28-year-old woman with clinical symptoms of PCOS and AMH serum level below analytical sensitivity $(<1.0 \mathrm{pmol} / \mathrm{L})$. After undergoing controlled ovarian stimulation, the patient developed OHSS. After follicle aspiration, seven oocytes were recovered. Three of them were used for intracytoplasmic sperm injection (ICSI) and fertilized, but with unsuccessful pregnancy outcome. A successful pregnancy was achieved in the second IVF/ICSI cycle with six oocytes retrieved and three embryos transferred. At 39 weeks of gestation, the patient delivered a healthy baby weighing $3930 \mathrm{~g}$ and $50 \mathrm{~cm}$ long. In conclusion, although $\mathrm{AMH}$ is considered a useful tool in ovarian reserve assessment and in predicting response to controlled ovarian hyperstimulation, the case presented shows that AMH should not be used as an independent ovarian marker.
\end{abstract}

Key words: Infertility; Ovarian hyperstimulation syndrome; Polycystic ovary syndrome; Anti-müllerian hormone; Reproductive techniques, assisted; Case reports

\section{Introduction}

Anti-müllerian hormone $(\mathrm{AMH})$ is mainly expressed in granulosa cells of the growing follicles recruited from the primordial pool in the ovaries until they reach the size of about $4-6 \mathrm{~mm}^{1}$. An active cohort of growing preantral and small antral follicles mainly contributes to serum levels of AMH. The serum concentration of AMH strongly correlates with the antral

Correspondence to: Ivan Grbavac, MD, Department of Gynecology and Obstetrics, Sestre milosrdnice University Hospital Centre, Vinogradska c. 29, HR-10000 Zagreb, Croatia

E-mail: ivan.grbavac1@gmail.com

Received November 12, 2015, accepted March 11, 2016 follicle count (AFC); both of them are more reliable markers in assessment of oocyte quantity and ovarian response during controlled ovarian stimulation (COS) than basal follicle-stimulating hormone (FSH), estradiol, and woman's age ${ }^{2}$. It has been demonstrated that in women with extremely low $(<1.0 \mathrm{pmol} / \mathrm{L})$ serum levels of $\mathrm{AMH}$ undergoing in vitro fertilization (IVF), one can predict poor ovarian response and chance for pregnancy irrespective of age and the COS protocol undertaken ${ }^{3}$. In women with polycystic ovary syndrome (PCOS), AMH serum concentrations are significantly higher than in women with normal ovaries, which correspond to the increased number of small antral follicles in the ovaries of women with $\mathrm{PCOS}^{4}$. 
Additionally, some investigators presented $\mathrm{AMH}$ and AFC as reliable markers in prediction of excessive response following $\mathrm{COS}^{5}$.

We report a case of a 28-year-old woman with clinical signs of PCOS and AMH serum level below analytical sensitivity $(<1.0 \mathrm{pmol} / \mathrm{L})$ who developed ovarian hyperstimulation syndrome (OHSS) after COS.

\section{Case Report}

A couple was referred for infertility treatment to the Human Reproduction Unit, Department of Gynecology and Obstetrics, Sestre milosrdnice University Hospital Center, Zagreb, Croatia. Semen analysis in the 29-year-old male partner showed teratozoospermia. The female was a 28-year-old nulligravida with irregular menstrual cycles and without clinical symptoms of PCOS. Ovulation induction with clomiphene citrate that had been performed earlier resulted in no oocytes retrieved. Ultrasound examination performed at the Department revealed enlarged ovaries with polycystic morphology. AFC was 12 in one ovary and 13 in the other. The patient had a slightly elevated body mass index (BMI, $\left.27.3 \mathrm{~kg} / \mathrm{m}^{2}\right)$, without clinical signs of hyperandrogenism. The hormonal status on day 5 of the menstrual cycle showed LH 10.4 IU/L (reference interval: 2.4-12.6 IU/L), FSH 6.4 IU/L (reference interval: 3.5-12.5 IU/L), estradiol 223 $\mathrm{pmol} / \mathrm{L}$ (reference interval: 80-790 pmol/L), TT 2.5 nmol/L (reference interval: 0.4-1.7 $\mathrm{nmol} / \mathrm{L}$ ), SHBG $64.6 \mathrm{nmol} / \mathrm{L}$ (reference interval: $17-125 \mathrm{nmol} / \mathrm{L}$ ), FT $29.2 \mathrm{pmol} / \mathrm{L}$ (reference interval: $1.0-33.0 \mathrm{pmol} / \mathrm{L}$ ) and DHEA-S $4.5 \mu \mathrm{mol} / \mathrm{L}$ (reference interval: 0.95-11.67 $\mu \mathrm{mol} / \mathrm{L})$. Serum levels of AMH (AMH Gen II ELISA, Beckman Coulter Inc., USA) and inhibin B (Inhibin B Gen II ELISA, Beckman Coulter Inc., USA) were $<1.0 \mathrm{pmol} / \mathrm{L}$ (reference interval: 7.1-71.4 $\mathrm{pmol} / \mathrm{L}$ ) and $30.2 \mathrm{pg} / \mathrm{mL}$ (reference interval: $10-273$ $\mathrm{pg} / \mathrm{mL}$ ), respectively. Progesterone concentration on day 21 was $2.4 \mathrm{nmol} / \mathrm{L}$ (reference interval: 5.3-86.0 $\mathrm{nmol} / \mathrm{L}$ ). Additional laboratory analyses confirmed normal thyroid function and no evidence of hyperprolactinemia or insulin resistance. An unexpectedly low $\mathrm{AMH}$ concentration in the clinical condition of our patient raised a question of the possible endogenous interferences in the serum sample analyzed ${ }^{6}$. Interferences of hemolysis, lipemia and hyperbilirubinemia were excluded by visual examination of the sample. For clinical suspicion of discordance between the clinical and laboratory data, an independent serum sample was analyzed for $\mathrm{AMH}$ in another laboratory, using a different analytical method (Immunotech; Beckman Coulter, Marseilles, France). The AMH concentration was again $<1.0 \mathrm{pmol} / \mathrm{L}$. Furthermore, AMH was measured in the patient's sample, successively diluted with serum of post-menopausal woman (Table 1).

Table 1. Anti-müllerian hormone (AMH) and estradiol serum concentrations through stimulation protocol

\begin{tabular}{|c|c|c|c|c|}
\hline \multirow[b]{2}{*}{$\begin{array}{l}\text { Serum } \\
\text { sample }\end{array}$} & \multicolumn{3}{|c|}{$\mathrm{AMH}(\mathrm{pmol} / \mathrm{L})$} & \multirow[b]{2}{*}{$\begin{array}{l}\text { Estradiol } \\
(\mathrm{pmol} / \mathrm{L})\end{array}$} \\
\hline & $\begin{array}{l}\text { Non- } \\
\text {-diluted }\end{array}$ & \begin{tabular}{|l} 
Diluted \\
1:10
\end{tabular} & \begin{tabular}{|l} 
Diluted \\
$1: 100$
\end{tabular} & \\
\hline Basal value & $<1.0$ & $<1.0$ & $<1.0$ & 223 \\
\hline $\begin{array}{l}\text { Stimulation } \\
\text { (day 12) }\end{array}$ & $<1.0$ & $<1.0$ & $<1.0$ & 17760 \\
\hline $\begin{array}{l}\text { Stimulation } \\
\text { (day 14) }\end{array}$ & $<1.0$ & $<1.0$ & $<1.0$ & 30845 \\
\hline $\begin{array}{l}\text { Stimulation } \\
\text { (day 19) }\end{array}$ & $<1.0$ & - & - & 33325 \\
\hline
\end{tabular}

Hormonal assessment performed in the follicular phase revealed elevated LH/FSH ratio and TT, and abnormal $\mathrm{P}$ concentrations in the luteal phase of the menstrual cycle. Biochemical hyperandrogenemia, anovulation combined with polycystic ovarian morphology and elevated BMI were the main criteria to diagnose PCOS in accordance with the Rotterdam classification ${ }^{7}$. Inhibin $\mathrm{B}$ and $\mathrm{AMH}$ concentrations were substantially below the expected values with regard to patient's age and PCOS diagnosis. Serial dilutions of serum samples, performed for suspicion of endogenous interferences, did not reveal any discrepancies in the $\mathrm{AMH}$ concentrations measured. After clinical evaluation, the couple was scheduled for assisted reproductive technique of IVF and intracytoplasmic sperm injection (ICSI). Controlled ovarian hyperstimulation $(\mathrm{COH})$ was initiated on the third day of the menstrual cycle with high dose recombinant FSH ( $\mathrm{rFSH}, \mathrm{Go}^{-}$ nal F, Merck Serono, Rome, Italy) and GnRH antagonist (cetrorelix, Cetrotide, Baxter Oncology GmbH, Frankfurt, Germany) to prevent premature ovulation. $\mathrm{COH}$ was monitored by transvaginal sonography, and thereafter the dose of gonadotropin was adjusted according to the follicle size and number. In total 1425 
IU of $\mathrm{rFSH}$ and $1 \mathrm{mg}$ of $\mathrm{GnRH}$ antagonist were administered. Ovulation was triggered on day 12 with $10000 \mathrm{IU}$ of human chorionic gonadotropin (hCG). In total, on the day of hCG administration, the patient developed numerous follicles and estradiol concentration of $30845 \mathrm{pmol} / \mathrm{L}$. After follicle aspiration, seven oocytes were recovered. Four metaphase II oocytes were retrieved by transvaginal aspiration and three underwent ICSI. Embryo transfer was not performed and all three embryos reached the blastocyst stage of development and were cryopreserved. Five days after oocyte retrieval, the patient presented to the Department with mild abdominal pain and abdominal distension. Ultrasonography revealed ascites and enlarged ovaries (10 $\mathrm{cm}$ and $9 \mathrm{~cm}$ in diameter). Laboratory evaluation confirmed OHSS with the following findings: elevated serum concentrations of CRP (32.9 $\mathrm{mg} / \mathrm{L}), \operatorname{AST}(45 \mathrm{U} / \mathrm{L})$ and ALT (48 U/L). Hemoglobin was $154 \mathrm{~g} / \mathrm{L}$, hematocrit $47 \%$, and leukocytes $22.9 \times 10^{9} / \mathrm{L}$. Total plasma proteins were low $(53 \mathrm{~g} / \mathrm{L})$. Electrolyte levels were normal. Within two days, owing to improved clinical status, the patient was discharged home. A frozen-thawed embryo transfer cycle was performed four months later, but the pregnancy failed. The second IVF-ICSI cycle was carried out one month later with $750 \mathrm{IU}$ of $\mathrm{rFSH}$ and $0.5 \mathrm{mg}$ of $\mathrm{GnRH}$ antagonist. Six oocytes were retrieved. Three of them were evaluated as metaphase II oocytes and underwent ICSI. The evaluation of the three embryos that were transferred on day 3 was as follows: embryo 1 (eight equal blastomeres without fragmentation), embryo 2 (eight equal blastomeres without fragmentation) and embryo 3 (six unequal blastomeres with 30\% fragmentation). Transfer procedure was performed by the COOK Embryo Transfer catheter. Pregnancy was established twelve days after embryo transfer with a positive beta hCG result (239 IU/L) and was confirmed by ultrasonography. The pregnancy continued to term without any complications. At 39 weeks of gestation, the patient delivered a healthy baby weighing $3930 \mathrm{~g}$ and $50 \mathrm{~cm}$ long.

This case report was approved by the institutional review board and the patient gave her verbal consent.

\section{Discussion}

To our knowledge, this is the first report of undetectable AMH serum level and subnormal level of in- hibin B in a patient with clinical condition of PCOS, who developed a moderate form of OHSS during ovarian stimulation. A previous report demonstrated $\mathrm{AMH}$ as a good predictive marker of ovarian responsiveness in women undergoing $\mathrm{COH}^{8}$. Moreover, AMH above $35 \mathrm{pmol} / \mathrm{L}$ and 19 follicles per ovary have been proposed as threshold levels for PCOS inclusion criteria ${ }^{4}$. A previous report demonstrated good correlation between $\mathrm{AMH}$ and $\mathrm{AFC}^{1}$. In our case, the patient had ovaries of polycystic morphology and therefore high levels of AMH would have been expected. $\mathrm{AMH}$ serum levels have been shown to be higher in women with PCOS than in those with normal ovaries, probably as the result of increased synthesis by granulosa cells and secretion of AMH in the polycystic ovaries $^{9}$. The increase in AMH concentration is largely due to the increase in the production of AMH by each follicle, and not just a consequence of an increase in follicle number ${ }^{10}$. The cause of increased $\mathrm{AMH}$ production in PCOS is unknown. However, in our study, $\mathrm{AMH}$ serum level was below analytical sensitivity. In addition, our patient had hyperandrogenism and PCOS. Women with hyperandrogenism and PCOS have been reported to have higher serum concentrations of AMH than women with PCOS and normal androgen concentrations ${ }^{11}$. This was not the case in our patient. However, a recent study showed that $\mathrm{AMH}$ concentration remained unchanged after 6 months of androgen suppression with dexamethasone ${ }^{12}$.

From the data presented, it has been inferred that, according to AMH levels, those patients would be categorized as poor responders and the occurrence of ongoing pregnancy would be highly unlikely ${ }^{8}$. Using the independent $\mathrm{AMH}$ analysis, we eliminated the possibility of an erroneous measurement. Also, by performing analyses in successively diluted serum, we obviated the possible 'hook effect' and the presence of endogenous antibodies, which could interfere in the $\mathrm{AMH}$ immunoassay ${ }^{6}$.

\section{Conclusion}

In conclusion, we report the occurrence of moderate OHSS and successful pregnancy outcome in a patient with undetectable AMH serum concentration. Although AMH is considered a useful tool in ovarian reserve assessment and in anticipating the $\mathrm{COH}$, the data presented show that $\mathrm{AMH}$ should not be used as 
an independent ovarian marker. Furthermore, any discordance between laboratory findings and clinical condition should be considered with more caution during the infertility treatment and IVF planning.

\section{References}

1. Visser JA, de Jong FH, Laven JS, Themmen AP. Anti-müllerian hormone: a new marker for ovarian function. Reproduction. 2006;131:19. https://doi.org/10.1093/humrep/den480

2. Zec I, Tišlarić-Medenjak D, Bukovec Megla Ž, Kučak I. Antimüllerian hormone: a unique biochemical marker of gonadal development and fertility in humans. Biochem Med. 2011; 21:219-30.

3. Nelson SM, Yates RW, Lyall H, Jamieson M, Traynor I, Gaudoin M, Mitchell P, Ambrose P, Fleming R. Anti-müllerian hormone-based approach to controlled ovarian stimulation for assisted conception. Hum Reprod. 2009;24:867-75.

https://doi.org/10.1093/humrep/den480

4. Dewailly D, Gronier H, Poncelet E, Robin G, Leroy M, Pigny P, Duhamel A, Catteau-Jonard S. Diagnosis of polycystic ovary syndrome (PCOS): revisiting the threshold values of follicle count on ultrasound and of the serum AMH level for the definition of polycystic ovaries. Hum Reprod. 2011;26:31239. https://doi.org/10.1093/humrep/der297

5. Broer SL, Dólleman M, Ompeer BC, Fauser BC, Mol BW, Broekmans FJM. AMH and AFC as predictors of excessive response in controlled ovarian hyperstimulation: a meta-analysis. Hum Reprod Update. 2011;17:4654.

https://doi.org/10.1093/humupd/dmq034
6. Dodig S. Interferences in quantitative immunochemical methods. Biochem Med. 2009;19:5062.

7. Rotterdam ESHRE/ASRM-sponsored PCOS Consensus Workshop Group. Revised 2003 consensus on diagnostic criteria and long term health risk related to polycystic ovary syndrome. Fertil Steril. 2004 Jan;81(1):19-25.

8. La Marca A, Sighinolfi G, Radi D, Argento C, Baraldi E, Artenisio AC, Stabile G, Volpe A. Anti-müllerian hormone $(\mathrm{AMH})$ as a predictive marker in assisted reproductive technology (ART). Hum Reprod Update. 2010;16:11330. https://doi.org/10.1093/humupd/dmp036

9. Mulders AG, Laven JS, Eijkemans MJ, de Jong FH, Themmen AP, Fauser BC. Changes in anti-mullerian hormone serum concentrations over time suggest delayed ovarian ageing in normogonadotrophic anovulatory infertility. Hum Reprod. 2004;19:2036-42. https://doi.org/10.1093/humrep/deh373

10. Pellat L, Rice S, Mason HD. Anti-müllerian hormone and polycystic ovary syndrome: a mountain too high? Reproduction. 2010;139:825-33. https://doi.org/10.1530/REP-09-0415

11. Eldar-Geva T, Margalioth EJ, Gal M, Ben-Chetrit A, Algur N, Zylber-Haran E, Brooks B, Huerta M, Spitz IM. Serum antimüllerian hormone levels during controlled ovarian hyperstimulation in women in polycystic ovaries with and without hyperandrogenism. Hum Reprod. 2005;20:1814-9.

https://doi.org/10.1093/humrep/deh873

12. Carlsen SM, Vanky E, Fleming R. Anti-müllerian hormone concentrations in androgen-suppressed women with polycystic ovary syndrome. Hum Reprod. 2009;24:1732-8. https://doi.org/10.1093/humrep/deh873

\section{Sažetak \\ NEMJERLJIVA RAZINA SERUMSKOG ANTI-MÜLLEROVA HORMONA U ŽENE SA SINDROMOM HIPERSTIMULACIJE JAJNIKA TIJEKOM IN VITRO FERTILIZACIJE I USPJEŠAN ISHOD TRUDNOĆE: PRIKAZ SLUČAJA}

\section{Grbavac, I. Zec, D. Ljiljak, R. RakošJustament, Ž. Bukovec Megla i K. Kuna}

Opisan je jedinstven slučaj nemjerljive serumske razine anti-Müllerova hormona (AMH) u žene sa sindromom policističnih jajnika (PCOS) koja je razvila sindrom hiperstimulacije jajnika (OHSS) tijekom in vitro oplodnje (IVF). Prikazujemo slučaj 28-godišnje žene s kliničkim simptomima PCOS-a i razine AMH u serumu ispod analitičke osjetljivosti $(<1,0$ pmol/L). Nakon što je prošla kroz kontroliranu stimulaciju jajnika, bolesnica je razvila OHSS. Aspiracijom folikula dobiveno je sedam jajnih stanica. Tri su oplođene metodom intracitoplazmatskog ubrizgavanja spermija (ICSI), ali s neuspješnim ishodom trudnoće. Do trudnoće je došlo u drugom ciklusu IVF/ICSI sa šest oocita i tri prenesena zametka. U 39. tjednu trudnoće žena je rodila zdravo dijete teško $3930 \mathrm{~g}$ i dugo $50 \mathrm{~cm}$. U zaključku, iako se AMH smatra korisnim testom u procjeni rezerve jajnika i u predviđanju odgovora na kontroliranu hiperstimulaciju jajnika, ovaj slučaj pokazuje da se AMH ne smije rabiti kao samostalan test procjene rezerve jajnika.

Ključne riječi: Neplodnost; Sindrom hiperstimulacije jajnika; Sindrom policističnih jajnika; Anti-Müllerov hormon; Začeće, potpomognuto, tehnike; Prikazi slučaja 